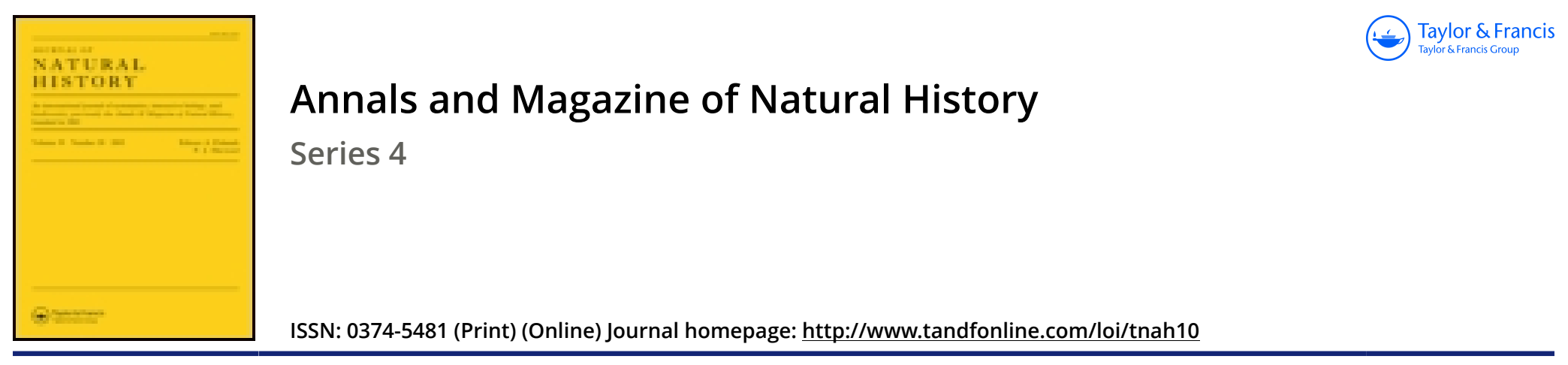

\title{
XL.-Descriptions of new species of Scincidæ in the collection of the British Museum
}

\section{A.W.E. O'Shaughnessy}

To cite this article: A.W.E. O'Shaughnessy (1874) XL.-Descriptions of new species of Scincidæ in the collection of the British Museum , Annals and Magazine of Natural History, 13:76, 298-301, DOI: $10.1080 / 00222937408680864$

To link to this article: http://dx.doi.org/10.1080/00222937408680864

\section{Published online: 13 Oct 2009.}

\section{Submit your article to this journal $\square$}

Џ Article views: 8

Q View related articles $\square$

Citing articles: 4 View citing articles $\square$ 
sima in segmentis I.-XI., in prioribus usque ad dorsum protenta. Pinnæ fasciculos setarum capillarium gerentes a segmento secundo per totum corpus obviæ, in segmentis anterioribus compressæ in dorso collocatæ supino vergentes, deinde subconicæ in lateribus segmentorum collocatæ postice versus spectantes; setæ longæ, sericeæ, limbatæ; uncinorum ventralium ordo prior sub pinna setigera quinta, in segmentis sequentibus in pinnula parva adpressa; uncini minutissimi 3-dentati uniseriales.

$H a b$. $59^{\circ} 34^{\prime}$ lat. bor., $7^{\circ} 18^{\prime}$ long. occid., fundo 650 orgyiarum.

Erlangæ, d. II. m. Martii MDCCCLXXIV.

XL.-Descriptions of new Species of Scincida in the Collection of the British Museum. By A. W. E. O'Shaughnessy, Assistant in the Zoological Department.

\section{Mocoa lichenigera, n. sp.}

Body cylindrical; lower eyelid with transparent disk; scales smooth, small, in 41 longitudinal series, those of the inferior surface being exceedingly numerous, considerably over 80 in a longitudinal series, the scales between the chest and chin being smaller than those on the belly; nasals and fronto-nasals not contiguous ; internasal almost circular; frontal widened anteriorly and tapering posteriorly; frontoparietals separate; supralabials six, subequal; ear-opening moderate.

Somewhat resembling Mocoa Smithii.

Colour: above olive or bronzed greenish brown, dotted with dark brown; sides with dark brown variegations, forming a wavy line along the margin of the back on each side, and extending on to the tail; lower surface pale yellowish.

Tail rather broad; scales small, uniform ; limbs moderate, fore and hind ones meeting in the middle of the side.

Lord Howe's Island. In the collection of the British Museum. Collected by Mr. M'Gillivray.

\section{Mocoa pretiosa, n. sp.}

Resembles $M$. Entrecasteauxii, but differs in the much greater number of scales; in the latter there are $56-59$ in a longitudinal ventral series, while in the present there are not less than 80. Fronto-parietals united; scales striated or minutely ridged. Colour: bright brown, with median black 
stripe and numerous small yellowish ocelli ; sides deep brown, with a bright yellowish wavy streak above and below.

The British Museum has received this species from Tasmania. Collected by R. Gunn, Esq.

\section{Mocoa mustelina, n. sp.}

Elongate and slender in form; head small ; limbs short and weak. Superficial resemblance to Hinulia ornata in coloration ; but, besides being distinctly a Mocou, it has much larger and fewer scales: there are 22-24 longitudinal rows as counted round the body, and 52 in a longitudinal ventral series; while in Hinulia ornata these numbers are respectively 30 and 62 . Colour: bright yellowish brown above, with small mottling:s and wavy lines and variegations along the sides, extending in regular streaks on the tail; lower surface pare white; chin dotted with brown; a pure white oblong spot immediately behind the eye.

The British Museum possesses three specimens from New South Wales.

\section{Mocoa microlepidota, n. sp.}

Body somewhat depressed. Scales small, those on the back distinctly three-ridged. Lower eyelid transparent. Nasals and fronto-nasals not contiguous ; internasal broad, saddleshaped; fronto-parietal single; no supranasals; 38 longitudinal series of scales as counted round the body, 83 in a longitudinal ventral series. Dorsal surface closely speckled with black and olive, a marginal olive stripe along upper edge of sides; sides with a deep band of dark brown, speckled and breaking into the æneous bluish green of the lower surface, which is also very minutely speckled with brown on the chin. Tail with small uniform scales; when reproduced, a single very broad series inferiorly.

In the collection of the British Museum, from Van Diemen's Land. From the Sydney Museum.

\section{Mocoa metallica, n. sp.}

Lower eyelid transparent; supranasals none. Scales distinctly four- or five-keeled, the projections being well defined but not sharp. Body stout, tetragonal; limbs rather short; ear-opening large. Nasals and fronto-nasals not contiguous; frontal short, triangular, of the same size as or smaller than the single fronto-parietal, which it joins with its truncated point. Supralabials six, the four anterior subequal, that under the eye more prolonged. Scales in 28 longitudinal series, the 
two median dorsal being very broad; in a longitudinal ventral row there are 60 , and these latter are smaller than the dorsal scales. Colours: above bright bronzed green, with a median dark brown stripe and lateral variegations more or less irregular; sides dark brown, broken up into irregular variegations; beneath greenish, dotted on chin.

In the British Museum, from Van Diemen's Land. Collected by R. Gunn, Esq.

In several other specimens (Dr. Millingen's collection) the ground-colour is much darker, and may be described as greenish brown, the pattern, however, being the same.

\section{Mocoa pseudocarinata, n. sp.}

Two small black skinks from Tasmania, also from Mr.Gunn's collection, present curiously ridged, or rather perhaps in. dented scales, three or four indentations being distinct towards the margin of all the scales, both dorsal and ventral. Lower eyelid transparent; no supranasals. Scales rather convex, distinct grooves between the series the whole length of the body. Fronto-parietals united in one specimen, in the other apparently separated by an irregular suture. Shining black above, with two narrow light stripes from head along the upper and lower margins of the sides. Scales in 28 longitudinal series, and 62 in ventral series.

\section{Mabouya punctatissima, n. sp.}

Supranasals narrow, oblique, contiguous; internasal broad, saddle-shaped; fronto-nasals contiguous, broad; fronto-parietals separate; supralabials seven, the five anterior subequal, that under the eye longer; ear-opening large. Scales moderate, rounded, smooth, equal all over the body; in 42 longitudinal series, 69 in a longitudinal ventral series. Hind legs not quite as long as the side, fore legs reaching to end of muzzle. Tail somewhat longer than head and body. Colour greenish brown, punctulated all over the upper surface with dark brown and occasional white dots; lower parts pale greenish.

The British Museum possesses one specimen of this form, which was purchased of M. Parzudaki, who gave the Cape of Good Hope as its locality, which we must consider very doubtful.

\section{Euprepes fogoensis, D. \& B.}

Superficially resembling E. Stangeri, but with much smaller 
scales, there being 56-60 longitudinal series, and 100 in a longitudinal ventral series. Scales two-keeled, uniform in size all over the body. Supranasals contiguous; fronto-nasals contiguous ; fronto-parietals separate; supralabials six; earopening moderate, rounded, with small scales anteriorly. Limbs moderate. Tail somewhat longer than head and body. Colour olive-brown ; two series of stria, consisting of minute ocellations of dark brown intersprinkled with whitish, forming almost two long stripes on each side of the back; sides brown, similarly variegated and mottled; belly pale; chin and chest variegated with brown.

Cape-Verde Islands. Many specimens, adult and young, from the islands of Fogo and St. Vincent's in the Cape-Verde group, from the collection of the Rev. R. T. Lowe.

By its two-keeled scales this species is allied to Macroscincus Coctei; but the teeth are not serrated.

\section{Diploglossus millepunctatus.}

Head elongate, flattened, broadening posteriorly; supranasals two pair, large, contiguous; nostrils in nasal shield, above suture between first and second labials, with a curved groove behind them; three large plates between eye and nasal ; internasal broad, tapering posteriorly, separating the two long semirhomboidal fronto-nasals. Frontal a broad and long shield meeting by an obtuse point the narrow interparietal and separating two fronto-parietals; large rounded parietal plates. Supraorbitals four, with inner supraoculars; supralabials ten. Ear of moderate size, open. Scales of body and tail small, rounded, smooth or with striæ obsolete; in about 56 longitudinal series, and 64 in a median dorsal series from shoulder to groin, and 116 scales in a longitudinal ventral series. Colour dark brown, with an infinite number of minute white specks, one, two, or three on every scale. Fore limbs, laid forwards, not reaching tip of snout, hind limbs reaching halfway along sides of body. tail.

Length of specimen 9 inches from tip of snout to root of

From the north-west coast of America. 